\title{
Influence of Different Postharvest Calcium Treatments and Storage Conditions on Quality of Peach cv. Shan-e-Punjab
}

\author{
Manpreet Singh*, Amit Jasrotia, Parshant Bakshi, Rafiq Ahmad Shah, \\ Rakesh Kumar and M. Iqbal Jeelani
}

\author{
Sher-e-Kashmir University of Agricultural Sciences and Technology of Jammu-180009, India \\ *Corresponding author
}

\section{A B S T R A C T}

A research was conducted to explore the effect of postharvest $\mathrm{CaCl}_{2}(2,4$ and 6\%) treatments on peach cv. Shan-e-Punjab, stored under ambient $\left(28\right.$ to $\left.30^{\circ} \mathrm{C}, 65-70 \% \mathrm{RH}\right)$ and refrigerated conditions $3+2{ }^{\circ} \mathrm{C}$ and $85-90 \% \mathrm{RH}$ in perforated polythene bags with

\section{Keywords}

Peach, Volume, Calcium chloride, Total Sugars.

\section{Article Info}

Accepted:

17 October 2017

Available Online:

10 December 2017 ethylene gas absorbent viz., potassium permanganate $\left(\mathrm{KMnO}_{4}\right)$. The quantitative and qualitative characteristics such as fruit volume, size (length and diameter), total sugars, reducing sugars and organoleptic evaluation i.e. sensory parameters like texture, taste, flavour and overall acceptability were studied at an interval of 3 days. It was interpreted that the loss in volume as well as size of peach fruit was reduced with the treatment of (6\%) $\mathrm{CaCl}_{2}$. It also maintained the total sugar and reducing sugar contents and organoleptic quality during storage. Maximum volume $(62.81 \mathrm{cc})$ was found in fruits treated with $6 \% \mathrm{CaCl}_{2}$ and stored under refrigerated conditions where as it was minimum (48.09 cc) in fruits kept under controlled in untreated fruits on $24^{\text {th }}$ day of storage. The fruits treated with $6 \% \mathrm{CaCl}_{2}$ showed maximum size $(4.34 \mathrm{~cm})$, total sugars $(8.93 \%)$ and reducing sugars $(4.86 \%)$ content on $24^{\text {th }}$ day under refrigerated conditions. Treatment $6 \%$ $\mathrm{CaCl}_{2}$ and packaging in perforated polythene bags at refrigerated temperature) retained maximum quality attributes and also got maximum score for organoleptic evaluation. Statistical analysis showed that treatments and storage intervals had a significant $(\mathrm{P}<0.05)$ effect on physico-chemical, characteristics and sensory analysis of peach fruit.

\section{Introduction}

Peach is a popular fruit worldwide because of its nutritional value, acceptable sugar-to-acid ratio and pleasant flavour. However, peaches have a short shelf life of less than 3-4 days at ambient temperature. The factors that contribute to the short shelf life of this fruit include rapid metabolism because of high respiration rate, fungal decay after harvest, weight loss, physiological disorders, internal browning and textural changes (Fishman et al., 1993; Tonini and Tura 1998). Cold storage is commonly used to slow down these processes and extend the shelf life of fruits. However, chilling injury occurs at low temperatures. This phenomenon has been reported for peaches (Campos-Vargas et al., 2006). It is important to develop alternative peach preservation methods that meet food safety policies and require easy procedures. Calcium chloride $\left(\mathrm{CaCl}_{2}\right)$, salicylic acid (SA) and gibberellic acid $\left(\mathrm{GA}_{3}\right)$ have been extensively studied for the commercial application of extending fruit preservation (Manganaris et al., 2007; Li et al., 2009; Luo 
et al., 2011). The postharvest application of $\mathrm{CaCl}_{2}$ enhances the storage life of peaches (Manganaris et al., 2007) and strawberries (Verdini et al., 2008) by reducing pectin solubility, delaying fruit ripening, decreasing decay rate, strengthening cell walls and maintaining firmness (Lara et al., 2004; Manganaris et al., 2007). This study could also serve as a practical guideline on peach cv. Shan-e-Punjab storage for both fruit producers and consumers.

\section{Materials and Methods}

The fruits of peach cv. 'Shan-e-Punjab' were harvested at mature stage from the Research orchards of Division of Fruit Science, Udheywalla, SKUAST-J during 2014-15. Immediately after harvest, fruit samples were shifted in the laboratory to remove field heat before giving chemical dip treatment. The fruits were washed in running tap water, cleaned and dried with a piece of muslin cloth. After drying sorted fruits were divided into equal lots and lots were coated with different concentrations of calcium chloride and sealed in perforated poly-bags with $1 \%$ perforation and stored at $3+2{ }^{\circ} \mathrm{C}$ and $85-90 \%$ $\mathrm{RH}$. Prior to storage, these samples were treated with $1 \% \mathrm{KMnO}_{4}$ except fruits kept under control treatment. The observations for various physico-chemical characteristics were made at an interval of 3 days.

\section{Loss in volume}

Volume of fruit was measured by water displacement method. The average of twenty fruits from each replication was calculated and expressed in cubic centimeter (cc).

\section{Fruit size}

Length and diameter of twenty fruits from each replication, which were selected earlier, was measured by using Vernier caliper. Mean diameter was calculated and expressed in centimeter $(\mathrm{cm})$.

\section{Fruit specific gravity}

Specific gravity of fruits was calculated by the following formula:

Specific gravity $=\frac{\text { Weight of fruit }(\mathrm{g})}{\text { Volume of fruit }(\mathrm{cc})}$

\section{Sugars}

Sugars were determined by Lane and Eynon (1923) method as detailed by Ranganna (1995).

\section{Organoleptic evaluation}

To assess consumer preference, sensory evaluation of experimental samples was conducted at different intervals of storage by semi trained taste panel of 7-8 judges. The samples were evaluated for colour, texture, taste, aroma and overall acceptability. Samples were served on coded plates. The judges scored the quality characteristics of each sample on nine-point hedonic scale. The overall acceptability of products was based upon the mean scores obtained from all those characters studied under test. The product with an overall score of 5 or above was considered acceptable.

\section{Results and Discussion}

Fruits stored under ambient conditions in perforated poly bags showed retention of maximum fruit volume in $6 \% \mathrm{CaCl}_{2}$ treatment (58.01 cc) and minimum fruit volume was found in untreated fruits $(54.04 \mathrm{cc})$ after 6 days of storage, while the corresponding retention of volume of fruits in those stored under refrigerated condition were $62.81 \mathrm{cc}$ $\left(6 \% \mathrm{CaCl}_{2}\right)$ and $61.31 \mathrm{cc}$ (untreated fruits) 
respectively, after 24 days of storage (Table 1). As volume losses were more in fruits stored under ambient conditions than those stored under refrigerated conditions. The losses in volume of peach fruit were due to moisture losses, hydrolysis of the cell wall content which results in loss in fruit size. The results of decreased length and diameter are in consonance with those obtained by Pruthi et al., (1960), Parihar and Bajpai (1982) in apples, and Bakshi et al., (2006), in peach.

The data interpreted a decrease in fruit size (length and diameter) with the increment of storage period but also it was seen that there is increment in fruit length as well as diameter with increasing $\mathrm{CaCl}_{2}$ concentration in fruits packed in polybags stored under ambient as well as refrigerated condition (Table 2 and 3 ). The losses in length, diameter, and volume of peach fruit were due to moisture losses which results in loss in fruit size. The results of decreased length and diameter are in consonance with those obtained by Pruthi et al., (1960), Parihar and Bajpai (1982) in apples and Bakshi et al., (2006) in peach. The increment of size in calcium treated fruits might be due to its accumulation in the cell walls leading to facilitation in the cross linking of the pectic polymers which increases wall strength and cell cohesion and reduces the rate of respiration (White and Broadly, 2003).

Specific gravity is the ratio of weight to volume and with the increase in storage period there is gradual decline in weight and subsequent loss in volume of fruit (Table 4). Thus, there was an overall decrease in specific gravity. Gangwar and Tripathi (1972) while studying the biochemical changes during ripening during storage of peach cultivar Sharbati reported that specific gravity of fruits decreased from 1.08 to 1.01 as the stage of fruit advanced from immature to ripe. They further reported a decline in fruit weight with ripening of fruit. The result is also in accordance with the findings of Bakshi et al., (2006), Sakhale et al., (2009) and Kapse (1993).

Table.1 Effect of different storage conditions and post-harvest treatments on volume (cc) of peach cv. Shan-e-Punjab packed in poly-bags

\begin{tabular}{|c|c|c|c|c|c|c|c|c|c|c|}
\hline \multirow{2}{*}{$\begin{array}{l}\text { Treatmen } \\
\mathrm{t}\end{array}$} & \multicolumn{10}{|c|}{ Storage interval (days) } \\
\hline & 0 & 3 & 6 & 9 & 12 & 15 & 18 & 21 & 24 & \\
\hline & \multicolumn{10}{|c|}{ Ambient conditions } \\
\hline $\mathrm{T}_{0}$ & 66.59 & 66.47 & 54.04 & F.N.A* & & & & & & \\
\hline $\mathrm{T}_{1}$ & 66.63 & 66.58 & 55.79 & F.N.A & & & & & & \\
\hline $\mathrm{T}_{2}$ & 66.73 & 66.43 & 56.57 & F.N.A & & & & & & \\
\hline $\mathrm{T}_{3}$ & 66.77 & 66.30 & 58.01 & F.N.A & & & & & & \\
\hline \multicolumn{2}{|c|}{$\mathrm{CD}(\mathrm{p} \leq 0.05)$} & \multicolumn{3}{|c|}{ Storage intervals $(S)=1.28$} & \multicolumn{4}{|c|}{ Treatments $(T)=0.93$} & \multicolumn{2}{|c|}{$\mathrm{S} \times \mathrm{T}=\mathrm{NS}$} \\
\hline & \multicolumn{10}{|c|}{ Refrigerated conditions } \\
\hline $\mathrm{T}_{0}$ & 65.87 & 65.24 & 64.81 & 64.21 & 63.49 & 62.81 & 62.34 & 61.95 & 61.31 & F.N.A* \\
\hline $\mathrm{T}_{1}$ & 65.78 & 65.47 & 64.63 & 64.1 & 63.34 & 62.86 & 62.64 & 62.28 & 61.39 & F.N.A \\
\hline $\mathrm{T}_{2}$ & 65.66 & 64.71 & 64.54 & 64.22 & 63.86 & 63.45 & 62.79 & 62.31 & 61.44 & F.N.A \\
\hline $\mathrm{T}_{3}$ & 65.76 & 65.36 & 64.65 & 64.12 & 63.85 & 63.54 & 63.28 & 63.27 & 62.81 & F.N.A \\
\hline \multicolumn{2}{|c|}{$\mathrm{CD}(\mathrm{p} \leq 0.05)$} & \multicolumn{3}{|c|}{ Storage intervals $(S)=0.20$} & \multicolumn{4}{|c|}{ Treatments $(\mathrm{T})=0.06$} & \multicolumn{2}{|c|}{$\mathrm{S} \times \mathrm{T}=0.27$} \\
\hline
\end{tabular}

*FNA: Fruit Not Acceptable 
Table.2 Effect of different storage conditions and post-harvest treatments on length $(\mathrm{cm})$ of peach cv. Shan-e-Punjab packed in poly-bags

\begin{tabular}{|c|c|c|c|c|c|c|c|c|c|c|}
\hline \multirow{2}{*}{$\begin{array}{l}\text { Treatme } \\
\text { nt }\end{array}$} & \multicolumn{10}{|c|}{ Storage interval (days) } \\
\hline & 0 & 3 & 6 & 9 & 12 & 15 & 18 & 21 & \multicolumn{2}{|l|}{24} \\
\hline & \multicolumn{10}{|c|}{ Ambient conditions } \\
\hline $\mathrm{T}_{0}$ & 4.73 & 4.55 & 3.59 & F.N.A* & & & & & & \\
\hline $\mathrm{T}_{1}$ & 4.75 & 4.6 & 3.64 & F.N.A & & & & & & \\
\hline $\mathrm{T}_{2}$ & 4.72 & 4.62 & 3.75 & F.N.A & & & & & & \\
\hline $\mathrm{T}_{3}$ & 4.70 & 4.65 & 3.86 & F.N.A & & & & & & \\
\hline \multicolumn{2}{|c|}{$\mathrm{CD}(\mathrm{p} \leq 0.05)$} & \multicolumn{4}{|c|}{ Storage intervals $(S)=0.02$} & \multicolumn{3}{|c|}{ Treatments $(\mathrm{T})=0.04$} & & $\mathrm{~S} \times \mathrm{T}=\mathrm{NS}$ \\
\hline & \multicolumn{10}{|c|}{ Refrigerated conditions } \\
\hline $\mathrm{T}_{0}$ & 4.53 & 4.48 & 4.44 & 4.4 & 4.34 & 4.3 & 4.25 & 4.2 & 4.15 & F.N.A* \\
\hline $\mathrm{T}_{1}$ & 4.48 & 4.45 & 4.42 & 4.39 & 4.36 & 4.33 & 4.3 & 4.26 & 4.23 & F.N.A \\
\hline $\mathrm{T}_{2}$ & 4.49 & 4.47 & 4.45 & 4.42 & 4.39 & 4.36 & 4.31 & 4.28 & 4.26 & F.N.A \\
\hline $\mathrm{T}_{3}$ & 4.55 & 4.52 & 4.5 & 4.48 & 4.46 & 4.43 & 4.4 & 4.37 & 4.34 & F.N.A \\
\hline \multicolumn{2}{|c|}{$\mathrm{CD}(\mathrm{p} \leq 0.05)$} & \multicolumn{4}{|c|}{ Storage intervals $(S)=0.01$} & \multicolumn{3}{|c|}{ Treatments $(T)=0.02$} & \multicolumn{2}{|c|}{$\mathrm{S} \times \mathrm{T}=0.03$} \\
\hline
\end{tabular}

*FNA: Fruit Not Acceptable

Table.3 Effect of different storage conditions and post-harvest treatments on diameter $(\mathrm{cm})$ of peach cv. Shan-e-Punjab packed in poly-bags

\begin{tabular}{|c|c|c|c|c|c|c|c|c|c|c|}
\hline \multirow{2}{*}{$\begin{array}{l}\text { Treatme } \\
\text { nt }\end{array}$} & \multicolumn{10}{|c|}{ Storage interval (days) } \\
\hline & 0 & 3 & 6 & 9 & 12 & 15 & 18 & 21 & 24 & \\
\hline \multicolumn{11}{|c|}{ Ambient conditions } \\
\hline $\mathrm{T}_{0}$ & 4.58 & 4.28 & 3.67 & \multicolumn{7}{|l|}{ F.N.A* } \\
\hline $\mathrm{T}_{1}$ & 4.83 & 4.70 & 3.72 & \multicolumn{7}{|l|}{ F.N.A } \\
\hline $\mathrm{T}_{2}$ & 4.70 & 4.62 & 4.07 & \multicolumn{7}{|l|}{ F.N.A } \\
\hline $\mathrm{T}_{3}$ & 4.72 & 4.64 & 4.15 & \multicolumn{7}{|l|}{ F.N.A } \\
\hline \multicolumn{2}{|c|}{$\mathrm{CD}(\mathrm{p} \leq 0.05)$} & \multicolumn{4}{|c|}{ Storage intervals $(S)=0.06$} & \multicolumn{4}{|c|}{ Treatments $(T)=0.08$} & $\mathrm{~S} \times \mathrm{T}=\mathrm{NS}$ \\
\hline & \multicolumn{10}{|c|}{ Refrigerated conditions } \\
\hline $\mathrm{T}_{0}$ & 4.65 & 4.61 & 4.57 & 4.54 & 4.51 & 4.49 & 4.46 & 4.42 & 4.39 & F.N.A* \\
\hline $\mathrm{T}_{1}$ & 4.68 & 4.66 & 4.63 & 4.60 & 4.58 & 4.56 & 4.54 & 4.51 & 4.47 & F.N.A \\
\hline $\mathrm{T}_{2}$ & 4.73 & 4.69 & 4.65 & 4.62 & 4.59 & 4.57 & 4.54 & 4.51 & 4.49 & F.N.A \\
\hline $\mathrm{T}_{3}$ & 4.75 & 4.73 & 4.71 & 4.69 & 4.67 & 4.65 & 4.63 & 4.60 & 4.57 & F.N.A \\
\hline \multicolumn{2}{|c|}{$\mathrm{CD}(\mathrm{p} \leq 0.05)$} & \multicolumn{4}{|c|}{ Storage intervals $(S)=0.01$} & \multicolumn{3}{|c|}{ Treatments $(T)=0.02$} & \multicolumn{2}{|c|}{$\mathrm{S} \times \mathrm{T}=0.01$} \\
\hline
\end{tabular}

*FNA: Fruit Not Acceptable 
Table.4 Effect of different storage conditions and post-harvest treatments on specific gravity of peach cv. Shan-e-Punjab packed in poly-bags

\begin{tabular}{|c|c|c|c|c|c|c|c|c|c|c|}
\hline \multirow{2}{*}{$\begin{array}{l}\text { Treatmen } \\
\mathrm{t}\end{array}$} & \multicolumn{10}{|c|}{ Storage interval (days) } \\
\hline & 0 & 3 & 6 & 9 & 12 & 15 & 18 & 21 & 24 & \\
\hline & \multicolumn{10}{|c|}{ Ambient conditions } \\
\hline $\mathrm{T}_{0}$ & 1.134 & 1.112 & 1.097 & \multicolumn{7}{|l|}{ F.N.A* } \\
\hline $\mathrm{T}_{1}$ & 1.138 & 1.116 & 1.108 & \multicolumn{7}{|l|}{ F.N.A } \\
\hline $\mathrm{T}_{2}$ & 1.135 & 1.122 & 1.118 & \multicolumn{7}{|l|}{ F.N.A } \\
\hline $\mathrm{T}_{3}$ & 1.134 & 1.125 & 1.120 & \multicolumn{7}{|l|}{ F.N.A } \\
\hline \multicolumn{2}{|c|}{$\mathrm{CD}(\mathrm{p} \leq 0.05)$} & \multicolumn{4}{|c|}{ Storage intervals $(S)=0.02$} & \multicolumn{3}{|c|}{ Treatments $(\mathrm{T})=0.01$} & \multicolumn{2}{|c|}{$\mathrm{S} \times \mathrm{T}=\mathrm{NS}$} \\
\hline & \multicolumn{10}{|c|}{ Refrigerated conditions } \\
\hline $\mathrm{T}_{0}$ & 1.144 & 1.141 & 1.137 & 1.133 & 1.129 & 1.126 & 1.122 & 1.118 & 1.117 & F.N.A* \\
\hline $\mathrm{T}_{1}$ & 1.146 & 1.143 & 1.142 & 1.138 & 1.134 & 1.128 & 1.124 & 1.122 & 1.119 & F.N.A \\
\hline $\mathrm{T}_{2}$ & 1.149 & 1.146 & 1.143 & 1.140 & 1.137 & 1.134 & 1.132 & 1.129 & 1.122 & F.N.A \\
\hline $\mathrm{T}_{3}$ & 1.147 & 1.145 & 1.143 & 1.141 & 1.139 & 1.137 & 1.135 & 1.132 & 1.129 & F.N.A \\
\hline \multicolumn{2}{|c|}{$\mathrm{CD}(\mathrm{p} \leq 0.05)$} & \multicolumn{4}{|c|}{ Storage intervals $(S)=0.001$} & \multicolumn{3}{|c|}{ Treatments $(T)=0.003$} & \multicolumn{2}{|c|}{$\mathrm{S} \times \mathrm{T}=0.003$} \\
\hline
\end{tabular}

*FNA: Fruit Not Acceptable

Table.5 Effect of different storage conditions and post-harvest treatments on total sugars (\%) of peach cv. Shan-e-Punjab packed in poly-bags

\begin{tabular}{|c|c|c|c|c|c|c|c|c|c|c|}
\hline \multirow{2}{*}{$\begin{array}{l}\text { Treatmen } \\
\mathrm{t}\end{array}$} & \multicolumn{10}{|c|}{ Storage interval (days) } \\
\hline & 0 & 3 & 6 & 9 & 12 & 15 & 18 & 21 & \multicolumn{2}{|l|}{24} \\
\hline & \multicolumn{10}{|c|}{ Ambient conditions } \\
\hline $\mathrm{T}_{0}$ & 8.28 & 9.17 & 9.96 & F.N.A* & & & & & & \\
\hline $\mathrm{T}_{1}$ & 8.28 & 9.14 & 9.93 & F.N.A & & & & & & \\
\hline $\mathrm{T}_{2}$ & 8.28 & 9.09 & 9.88 & F.N.A & & & & & & \\
\hline $\mathrm{T}_{3}$ & 8.28 & 9.03 & 9.82 & F.N.A & & & & & & \\
\hline \multicolumn{2}{|c|}{$\mathrm{CD}(\mathrm{p} \leq 0.05)$} & \multicolumn{4}{|c|}{ Storage intervals $(S)=N S$} & \multicolumn{3}{|c|}{ Treatments $(T)=0.02$} & \multicolumn{2}{|c|}{$\mathrm{S} \times \mathrm{T}=\mathrm{NS}$} \\
\hline & \multicolumn{10}{|c|}{ Refrigerated conditions } \\
\hline $\mathrm{T}_{0}$ & 8.28 & 8.44 & 8.59 & 8.78 & 9.00 & 9.22 & 9.44 & 9.69 & 9.16 & F.N.A* \\
\hline $\mathrm{T}_{1}$ & 8.28 & 8.40 & 8.54 & 8.73 & 8.96 & 9.16 & 9.39 & 9.61 & 9.08 & F.N.A \\
\hline $\mathrm{T}_{2}$ & 8.28 & 8.37 & 8.51 & 8.66 & 8.91 & 9.11 & 9.33 & 9.45 & 9.00 & F.N.A \\
\hline $\mathrm{T}_{3}$ & 8.28 & 8.33 & 8.46 & 8.61 & 8.86 & 9.06 & 9.27 & 9.40 & 8.93 & F.N.A \\
\hline \multicolumn{2}{|c|}{$\mathrm{CD}(\mathrm{p} \leq 0.05)$} & \multicolumn{4}{|c|}{ Storage intervals $(S)=0.01$} & \multicolumn{3}{|c|}{ Treatments $(T)=0.01$} & \multicolumn{2}{|c|}{$\mathrm{S} \times \mathrm{T}=0.04$} \\
\hline
\end{tabular}

*FNA: Fruit Not Acceptable 
Table.6 Effect of different storage conditions and post-harvest treatments on reducing sugars (\%) of peach cv. Shan-e-Punjab packed in poly-bags

\begin{tabular}{|c|c|c|c|c|c|c|c|c|c|c|}
\hline \multirow{2}{*}{$\begin{array}{l}\text { Treatmen } \\
\mathrm{t}\end{array}$} & \multicolumn{10}{|c|}{ Storage interval (days) } \\
\hline & 0 & 3 & 6 & 9 & 12 & 15 & 18 & 21 & 24 & \\
\hline & \multicolumn{10}{|c|}{ Ambient conditions } \\
\hline $\mathrm{T}_{0}$ & 4.42 & 4.92 & 5.28 & F.N.A* & & & & & & \\
\hline $\mathrm{T}_{1}$ & 4.42 & 4.89 & 5.25 & F.N.A & & & & & & \\
\hline $\mathrm{T}_{2}$ & 4.42 & 4.86 & 5.22 & F.N.A & & & & & & \\
\hline $\mathrm{T}_{3}$ & 4.42 & 4.83 & 5.19 & F.N.A & & & & & & \\
\hline \multicolumn{2}{|c|}{$\mathrm{CD}(\mathrm{p} \leq 0.05)$} & \multicolumn{4}{|c|}{ Storage intervals $(S)=0.19$} & \multicolumn{3}{|c|}{ Treatments $(T)=0.01$} & \multicolumn{2}{|c|}{$\mathrm{S} \times \mathrm{T}=\mathrm{NS}$} \\
\hline & \multicolumn{10}{|c|}{ Refrigerated conditions } \\
\hline $\mathrm{T}_{0}$ & 4.42 & 4.5 & 4.58 & 4.67 & 4.76 & 4.86 & 4.96 & 5.08 & 4.98 & F.N.A* \\
\hline $\mathrm{T}_{1}$ & 4.42 & 4.48 & 4.55 & 4.65 & 4.74 & 4.83 & 4.94 & 5.03 & 4.95 & F.N.A \\
\hline $\mathrm{T}_{2}$ & 4.42 & 4.46 & 4.53 & 4.62 & 4.71 & 4.8 & 4.91 & 5.00 & 4.90 & F.N.A \\
\hline $\mathrm{T}_{3}$ & 4.42 & 4.45 & 4.51 & 4.6 & 4.69 & 4.78 & 4.89 & 4.97 & 4.86 & F.N.A \\
\hline \multicolumn{2}{|c|}{$\mathrm{CD}(\mathrm{p} \leq 0.05)$} & \multicolumn{4}{|c|}{ Storage intervals $(S)=0.05$} & \multicolumn{3}{|c|}{ Treatments $(T)=0.03$} & \multicolumn{2}{|c|}{$\mathrm{S} \times \mathrm{T}=0.07$} \\
\hline
\end{tabular}

*FNA: Fruit Not Acceptable

Table.7 Organo-leptic analysis of Shan-e-Punjab peach fruits packed in polybags under different storage conditions and post-harvest treatments

\begin{tabular}{|c|c|c|c|c|c|c|c|c|c|}
\hline \multirow{2}{*}{$\begin{array}{l}\text { Treatmen } \\
\mathrm{t}\end{array}$} & \multicolumn{9}{|c|}{ Storage interval (days) } \\
\hline & 0 & 3 & 6 & 9 & 12 & 15 & 18 & 21 & 24 \\
\hline \multicolumn{10}{|c|}{ Ambient condition } \\
\hline $\mathrm{T}_{0}$ & $\begin{array}{l}7 . \\
0\end{array}$ & 7.5 & 5.5 & F.N.A* & & & & & \\
\hline $\mathrm{T}_{1}$ & $\begin{array}{l}7 . \\
0\end{array}$ & 7.5 & 6.0 & F.N.A & & & & & \\
\hline $\mathrm{T}_{2}$ & $\begin{array}{l}7 . \\
0\end{array}$ & 8.0 & 6.5 & F.N.A & & & & & \\
\hline $\mathrm{T}_{3}$ & $\begin{array}{l}7 . \\
0\end{array}$ & 8.5 & 7.0 & F.N.A & & & & & \\
\hline
\end{tabular}

Refrigerated conditions

$\begin{array}{lllllllllll}\mathrm{T}_{0} & 7.0 & 7.5 & 8.5 & 8.0 & 8.0 & 7.5 & 7.0 & 6.0 & 5.0 & \text { *F.N.A } \\ \mathrm{T}_{1} & 7.0 & 8.0 & 8.5 & 9.0 & 8.5 & 8.5 & 7.5 & 6.5 & 5.5 & \text { *F.N.A } \\ \mathrm{T}_{2} & 7.0 & 7.5 & 8.0 & 8.5 & 9.0 & 8.5 & 7.5 & 6.0 & 5.5 & \text { *F.N.A } \\ \mathrm{T}_{3} & 7.0 & 8.0 & 8.5 & 9.0 & 9.5 & 8.5 & 8.0 & 6.5 & 6.0 & \text { *F.N.A }\end{array}$

* F.N.A. Fruit not acceptable 
In general, an increase in total sugar and reducing sugar content with increase in storage intervals was observed in all the treatments under room temperature as well as refrigerated conditions whereas it showed that with the increase in concentration of $\mathrm{CaCl}_{2}$ there was decrement in sugar content in all the treatments (Table 5 and 6). Maximum reducing sugar content was recorded in fruits which were untreated while minimum reducing sugar content was recorded in the fruits treated with $6 \% \mathrm{CaCl}_{2}$ under both the storage conditions (ambient as well as refrigerated) and same was with the total sugars, this may be a consequence of release of sugar during starch hydrolysis. Peach is a climacteric fruit, rich in starch reserves and during post -harvest storage starch is hydrolyzed and liberating reducing sugars with its enhancement during storage (Parmar and Chundawat, 1988, Kapse, 1993). Kaur et al., (2005) while working on pear by using different concentrations of calcium chloride solutions (4, 6 and 8\%) and thereafter, individually wrapping in different wrappers, viz. newspaper, polyethylene and butter paper, reported an increase in total and reducing sugars in fruits at ambient temperature. Singh et al., (1998) reported the effect of perforated polythene wrapping and pre-harvest application of calcium compounds on storage life of mango cv. Amrapali and observed that perforated polythene wrapping, calcium chloride $(1.5 \%)$ and calcium nitrate $(1.5 \%)$ treatments maintained the minimum reducing and total sugars during storage. Similar findings were also reported by Vanoli et al., (1995) and Bakshi and Masoodi (2009) during storage of peach fruits

It can be conjectured from the Table 7 that organoleptic value of the fruits packed in polybags, initially showed an increasing trend but with the advancement in storage intervals there was decrease in organoleptic value, while as with the increase in concentration of
$\mathrm{CaCl}_{2}$ in respective treatments showed almost an increasing trend in fruits stored under both ambient and refrigerated conditions at $6^{\text {th }}$ day and $24^{\text {th }}$ day of storage intervals respectively. The maximum organoleptic value was recorded in fruits treated with $6 \% \mathrm{CaCl}_{2}$, while as minimum was observed in untreated fruits stored under both ambient and refrigerated conditions

From the current studies it can be concluded that immersion of low chilling peach $\mathrm{cv}$. Shan-e- Punjab in calcium chloride at $6 \%$ could be used for prolonging the shelf life for handling fruits destined for, since it enables fruits with better qualitative characteristics (maintenance of tissue firmness, sugars, length, breadth and overall organoleptic characteristics).

\section{References}

Bakshi P and Masoodi FA. 2009. Effect of various storage conditions on chemical characteristics and processing of peach cv.'Flordasun'. Journal of Food Science and Technology 46: 271-274.

Bakshi P, Masoodi FA and Singh AK. 2006. Effect of pre-storage heat treatment on peach quality I. Physical characteristics. Indian Journal of Horticulture 63:365367.

Campos-Vargas R, Becerra O, Baeza-Yates R, Cambiazo V, González M, Meisel L, Orellana A, Retamales J, Silva H. and Defilippi B G. 2006. Seasonal variation in the development of chilling injury in 'O'Henry' peaches. Scientia Horticulturae 110:79-83.

Fishman M L, Levaj B, Gillespie D and Scorza R. 1993. Changes in the physico-chemical properties of peach fruit pectin during on-tree ripening and storage. Journal of the American Society for Horticultural Science 118:.343-349. 
Gangwar B M and Tripathi R S. 1972. Study on biochemical changes during ripening and storage of peach. Punjab Horticulture Journal, 4: 234-239

Kapse B M. (1993). An integrated approach to pos t-harvest handling of mango $\mathrm{cv}$. Kesar. Ph. D. Thesis submitted to GAU, S.K. Nagar.

Kaur N, Jawandha S K and Singh H. 2015. Effect of Calcium and Shrink Film on Post-Harvest Behavior of Cold Stored Plum Fruits. International Journal of Agriculture Environment and Biotechnology 8:951.

Lane J H and Eynon L. 1923. Methods for determination of reducing and nonreducing sugars. Journal of Science 42:32-37.

Lara I, Garcia P and Vendrell M. 2004. Modifications in cell wall composition after cold storage of calcium-treated strawberry (Fragaria $\times$ ananassa Duch.) fruit. Postharvest Biology and Technology 34:331-339.

Li F, Zhang Z, Li S, Xie M, Zhao C and Wang Y. 2009. Effects of gibberellic acid $\left(\mathrm{GA}_{3}\right)$ treatments on postharvest physiology and quality of sweet cherries. Science Technology Food Industry 10: 301-304.

Luo Z, Chen C and Xie J, 2011. Effect of salicylic acid treatment on alleviating postharvest chilling injury of 'Qingnai' plum fruit. Postharvest Biology and Technology, 62:115-120.

Manganaris G A, Vasilakakis M, Diamantidis $\mathrm{G}$ and Mignani I. 2007. The effect of postharvest calcium application on tissue calcium concentration, quality attributes, incidence of flesh browning and cell wall physicochemical aspects of peach fruits. Food Chemistry 100:1385-1392.

Panse V G and Sukhatme P V. 1985. Statistical Methods of Agricultural Workers. I.C.A.R., New Delhi.

Parihar M C and Bajpai P N. 1982. Storage losses in apple (Malus pumila Mill.). The Punjab Horticulture Journal 22:9598.

Parmar P B and Chundawat B S. 1988. Effect of various postharvest treatments on the physiology of Kesar mango. Acta Horticulture 231: 679-684.

Pruthi JS, Parekh CM and Lal G. 1960. Varietal differences In: physicochemical characteristics of Indian apples. Food Science, 9

Ranganna S. 1997. Handbook of Analysis and Quality Control of Fruits and Vegetable Products. $2^{\text {nd }}$ edn. Tata McGraw Hill Publishing Co., Calcutta, pp. 279-309.

Sakhale BK, Pawar VN and Kapse B M. 2009. Studies on the extension of shelf life of Kesar mango. Acta Horticulture 820: 643-651

Tonini G and Tura E. 1998. Influence of storage and shelf-life time on rots of peaches and nectarines. Acta Horticulturae 464: 364-367

Vanoli M, Visai C and Rizzolo A. 1995. Peach quality: influence of ripening and cold storage. Acta Horticulturae 379: 445-449.

White P J and Broadley M R. 2003. Calcium in plants. Annals of Botany 92: 487-511.

\section{How to cite this article:}

Manpreet Singh, Amit Jasrotia, Parshant Bakshi, Rafiq Ahmad Shah, Rakesh Kumar and Iqbal Jeelani, M. 2017. Influence of Different Postharvest Calcium Treatments and Storage Conditions on Quality of Peach cv. Shan-e-Punjab. Int.J.Curr.Microbiol.App.Sci. 6(12): 24592466. doi: https://doi.org/10.20546/ijcmas.2017.612.285 